\title{
CHANGES IN WATER AVAILABILITY IN THE SOIL DUE TO TRACTOR TRAFFIC
}

\section{KATHERINE GÓMEZ-RODRÍGUEZ ${ }^{1}$, JESÚS H. CAMACHO-TAMAYO ${ }^{2}$, JAVIER E. VÉLEZ-SÁNCHEZ ${ }^{3}$}

\begin{abstract}
Frequent traffic of tractors in agricultural soils, promotes soil compaction and affects the flow and water availability. The aim of this research was to study the effect of compaction induced by tractor traffic on water availability in the soil under different traffic intensities on the same path $(0,1,3,6$ and 10 passages), to two tractors with 3.3 and 2.6 ton of weights, over three different surface conditions. The study was conducted in an Andisol, representative soil of the study area. It was determined the behavior of the water retention curve, obtaining the gravitational water, available water and hygroscopic water, to 10 and $30 \mathrm{~cm}$ of depth. The hygroscopic water is the most prevalent with values of up to $80 \%$ of the total water present in the soil. The water retention curves showed increases in the values of field capacity and wilting point and behaviors "flattened" indicating a high sensitivity to the applied treatments, representative of compacted soils, which give the surfaces studied characteristics do not suitable for normal crop development.
\end{abstract}

KEYWORDS: compaction, soil management, water retention curve, Andisol.

\section{MUDANÇAS NA DISPONIBILIDADE DE ÁGUA DO SOLO DEVIDO AO TRÁFEGO DE TRATORES}

RESUMO: O tráfego frequente de tratores em solos agrícolas favorece a compactação dos solos e afeta o fluxo e a disponibilidade da água. O objetivo do presente trabalho foi estudar o efeito da compactação induzida pelo tráfego do trator na disponibilidade de água do solo, sob diferentes intensidades de trânsito sobre o mesmo caminho $(0,1,3,6$ e 10 passadas), para dois tratores com pesos de 3,3 e 2,6 ton, em três condições de superfície diferentes. O estudo foi desenvolvido em um Andisol, solo representativo da zona estudada. Determinou-se o comportamento da curva de retenção de umidade, obtendo-se a água gravitacional, a água disponível e água higroscópica, a profundidades de 10 e $30 \mathrm{~cm}$. Encontrou-se uma predominância da água higroscópica com valores de até $80 \%$ da água total presente no solo. As curvas de retenção de umidade apresentaram incrementos nos valores de capacidade de campo e ponto de murchamento permanente e com comportamentos "achatados" indicando uma alta sensibilidade aos tratamentos aplicados, representativa de solos compactados, o qual confere às superfícies estudadas características não aptas para o desenvolvimento normal de culturas.

PALAVRAS CHAVE: compactação, manejo de solos, curva de retenção de água, Andisol.

\section{INTRODUCTION}

Among the main causes of soil degradation in agricultural production, it is vehicle traffic, especially on physical attributes such as porosity and density (KAMIMURA et al., 2009). The use of tractor as main vehicle used in agriculture because of its versatility is of great importance since soil degradation by its merely transit is of important magnitude. JORAJURIA \& DRAGHIL (2000) claim that in the tenth passage of a light tractor (4.2 ton), the optimum conditions for crop development is lost, this to moistures above field capacity. BOTTA et al. (2009) manifested that the

\footnotetext{
${ }^{1}$ Ing. Agrícola, M. Sc., Universidad Nacional de Colombia, Facultad de Ingeniería, Departamento de Ingeniería Civil y Agrícola, Bogotá D.C.; kgomezro@unal.edu.co.

${ }^{2}$ Profesor Asistente, Ph. D., Universidad Nacional de Colombia, Facultad de Ingeniería, Departamento de Ingeniería Civil y Agrícola, Bogotá D.C.; jhcamachot@unal.edu.co.

${ }^{3}$ Profesor Asociado, Ph. D., Universidad Nacional de Colombia, Facultad de Ingeniería, Departamento de Ingeniería Civil y Agrícola, Bogotá D.C.; jevelezs@unal.edu.co.
} 
second and the following passages of the tractor cause less compaction than the first, being the fifth passage responsible for compaction in the soil surface layer agreeing with numerous studies cited by the aforementioned author and TOLON BECERRA et al. (2010) ensure that up the fifth passage the pressure exerted on the ground by a tractor 2WD FWA, causes surface compaction.

The changes or behaviors in several soil physical properties and their interrelations are great tools to measure the state of degradation of a soil. Properties such as bulk density of a soil, influence the behavior of porosity and water availability in the soil, affecting the reserve, the water and nutrient movement to the crop roots. GERSTER et al. (2008) found changes in sectors transited by agricultural implements, showing increases in bulk density, in soil resistance and in the moisture content at field capacity and in the permanent wilting point, while the water content to saturation and the gravitational water were lower with respect to those sectors that received no traffic.

The water availability in a soil is affected by countless parameters, which are the vehicle traffic , the texture, the moisture content, the soil particle size, the state of degradation, the plowing, among others (BOTTA et al., 2012; CAMACHO-TAMAYO \& RODRIGUEZ, 2007). The relation between the soil water content and the strength that is retained is determined usually by the moisture retention curve, because as the soil moisture content decreases, it requires more energy to extract the retained water (FU et al., 2011). PIRES et al. (2005) claim that the values of field capacity (FC) and permanent wilting point (PWP) can be deduced from the behavior of the moisture retention curve when applying voltages between 0.1 to 0.3 bars for DC and voltages above 15 bars for PWP. MADDEN (2010) classifies the presence of water in the soil as gravitational water, available and hygroscopic. SERAFIM et al. (2008) reported that changes in the bulk density and porosity alter the soil moisture retention, at the same time the retention curves are found flatten as the compression increases. LIPIEC et al. (2009) found that the behavior of the hydraulic properties is largely dependent on the interactions between the level of compaction, the aggregate size and the depth studied.

The aim of this study was to investigate the influence of compaction caused by a tractor on the water availability in a soil and the ways in which it is presented and varies as it receives higher traffic intensity.

\section{MATERIALS AND METHODS}

The study was conducted in Marengo Agricultural Center (MAC), located in the city of Mosquera - Cundinamarca at 2,543 m altitude, with geographic coordinates $4^{\circ} 42^{\prime} \mathrm{N}$ and $74^{\circ} 12^{\prime} \mathrm{W}$. The area has an average annual temperature of $13.1^{\circ} \mathrm{C}$ and average annual rainfall of $665 \mathrm{~mm}$. The soil belongs to the Marengo serie, originated from lacustrine sediments with volcanic ash debris and contribution of alluvial clays presenting a poor natural drainage (IGAC, 1977). The morphology of the soil profile shows dark brown color, with frank textures in the plow layer, with percentages of sand, silt and clay of $36 \%, 44 \%$ and $21 \%$ respectively, and average bulk density of $2.22 \mathrm{~g} \mathrm{~cm}^{-3}$.

The model considered 27 treatments evaluated through a completely randomized block design, which was verified the traffic influence of two tractors with aligned tires at different traffic intensities (1, 3, 6 and 10 passages) on three surfaces with different uses, considering a control for each surface. The passages were carried out continuously over the own tractor mark and to avoid edge effects, it was allowed a distance of 3 meters between the experimental plots. The characteristics of the tractors and the surfaces can be observed in Table 1 and 2, respectively. For each treatment, were carried out four replicates, in a total of 108 experimental plots, each one measuring $4 \mathrm{~m}$ X $20 \mathrm{~m}$. 
TABLE 1. Characteristics of the tractors used.

\begin{tabular}{lcc}
\hline \multicolumn{1}{c}{ Characteristics } & Tractor 1 (T1) & Tractor 2 (T2) \\
\hline Power & $46 \mathrm{~kW}(62.8 \mathrm{HP})(2 \mathrm{WD})$ & $48 \mathrm{~kW}(65.3 \mathrm{HP})(\mathrm{FWA})$ \\
Length & $3735 \mathrm{~mm}$ & $3415 \mathrm{~mm}$ \\
Width & $2060 \mathrm{~mm}$ & $1830 \mathrm{~mm}$ \\
Height & $2450 \mathrm{~mm}$ & $1650 \mathrm{~mm}$ \\
Track width & $1247 \mathrm{~mm}$ & $1119 \mathrm{~mm}$ \\
Wheelbase & $2280 \mathrm{~mm}$ & $2115 \mathrm{~mm}$ \\
Total weight & $3360 \mathrm{~kg}$ & $2614 \mathrm{~kg}$ \\
Static forward mass & $1008 \mathrm{~kg}$ & $1046 \mathrm{~kg}$ \\
Static rear mass & $2352 \mathrm{~kg}$ & $1568 \mathrm{~kg}$ \\
Forward pressure applied to the soil & $104.88 \mathrm{kPa}$ & $59.53 \mathrm{kPa}$ \\
Back pressure applied to the soil & $67.82 \mathrm{kPa}^{-1}$ & $52.82 \mathrm{kPa}$ \\
Operation speed & $5.5 \mathrm{~km} \mathrm{~h}^{-1}$ & $5.6 \mathrm{~km} \mathrm{~h}^{-1}$ \\
Tires & F 7.5-16/ B 18.4-30 & F 11.2-24 / B 14.9-30 \\
\hline
\end{tabular}

TABLE 2. Description of the traffic surfaces.

\begin{tabular}{llc}
\hline \multicolumn{1}{c}{ Use } & \multicolumn{1}{c}{ Description } & MC, \% ${ }^{(1)}$ \\
\hline Prepared (PR) & 1 plow, two plow with eccentric disc & 44.19 \\
Pasture (P1) & Kikuyo Pasture (Pennisetum clandestinum) & 31.10 \\
Pasture (P2) & Kikuyo Pasture (Pennisetum clandestinum) & 41.36 \\
\hline
\end{tabular}

(1) Gravimetric moisture content

During the essay, the tractors were not working neither showed attached implements, not showing therefore weight transference to the rear tires. The pressure exerted by the tires on the soil was estimated from the front and rear static weights informed by the manufacturers and the contact area calculated from Equation 1 proposed by INNS \& KILGOUR (1978), authors who resembled the contact area with a rectangle.

$$
A=(0.87 b) *(0.31 d)
$$

where $A$ is the contact area, $b$ is the tire mean width when it is filled with the correct pressure and $d$ is the overall diameter.

To find the characteristic curve of water retention of the soil, was used membrane equipment and pressure cookers, between 0.1 and 15 bar, including the saturation point ( 0 bar). Such curve resulted the dots between field capacity (FC) and permanent wilting point (PWP), providing the information on available water in the studied soil. The obtained curves have been adjusted to the VAN GENUCHTEN model (1980). From the information provided by the curve, it was found the gravitational water $(\mathrm{GW})$, the available water (AW) and the hygroscopic water (HG) (Equations 2, 3 and 4) (FLORES \& ALCALÁ, 2010):

$$
\begin{aligned}
& G W(\%)=P_{\text {sat }}-F C \\
& A W(\%)=F C-P W P \\
& H G(\%)=P W P
\end{aligned}
$$

where,

$\mathrm{P}_{\text {sat }}$ : Moisture content at saturation $\left(\mathrm{cm}^{3} \mathrm{~cm}^{-3}\right)$,

FC: Moisture content at 0.3 bar $\left(\mathrm{cm}^{3} \mathrm{~cm}^{-3}\right)$,

PWP: Moisture content at 15 bar $\left(\mathrm{cm}^{3} \mathrm{~cm}^{-3}\right)$.

\section{RESULTS AND DISCUSSION}


It was found for each treatment the moisture retention curve (Figures 1 and 2), these were adjusted to the GENUCHTEN VAN model (1980), which have correlation coefficients between 95.7\% and $99.8 \%$, indicating an optimal adjustment to this model. The values of FC and PWP is found at pressures between 0.3 and 15 bar, according to the methodology described by PIRES et al. (2005). The curves found have typical behavior of loam soil in accordance with studies from GHANBARIAN-ALAVIJEH et al. (2010). The values of field capacity range from 0.32 to $0.55 \mathrm{~cm}^{3}$ $\mathrm{cm}^{-3}$, which is higher on the P2 surface. These values agree with the above by MEZA \& GEISSERT (2003) for andic soils.

Generally it can be noted the increasing in the water retention of the soil studied with the load applied to the soil, as it was also reported by SEVERIANO et al. (2011). The behavior of the curves at $10 \mathrm{~cm}$ depth did not show a general trend, being noticed increments in the moisture content in the PR soil, on the total of the evaluated treatments, these increments are found between $21.6 \%$ and $51.9 \%$ to FC and between $20.0 \%$ and $55.1 \%$ in PWP, presenting the highest values in the third passage of both tractors. In the second studied depth $(30 \mathrm{~cm})$, the retention curve shows lower increases in the moisture content, but is still predominating the ascending behavior with increments between $8.17 \%$ to $32.1 \%$ the FC and between $15.6 \%$ to $46,1 \%$ for PWP, exerting greatest influence on the third passage, in the same way as in the first $10 \mathrm{~cm}$ depth. This behavior is cited by ALAOUI et al. (2011), when presenting compression increments.

As regards the variation of the retention curve for treatments with P1 and P2 vegetation cover, the behaviors are mutually contradictory, because to the P1 surface it presents increases in respect to the control with the exception of the tenth passage of the Tractor at 2 to $10 \mathrm{~cm}$ depth while the P2 soil the tendency is decreasing with respect to the control, considering both depths studied. The decreases of the P2 values are between 0.6 and 29.2\%, showing greater reduction on the sixth passage of tractor 1 to FC and PWP respectively. At $30 \mathrm{~cm}$ depth, the declines were of lower magnitude, with a maximum reduction of $10.4 \%$ of the control on the first passage of tractor 1 .

The curves have a "flat" behave, which reflect the distribution of pores, noticing a greater presence of small pores in the studied soils, which is in agreement with that found by DIJCK \& ASCH (2002). This flat tendency in the retention curve shows a clear impact of soil compaction, reducing the interval between FC and PWP.

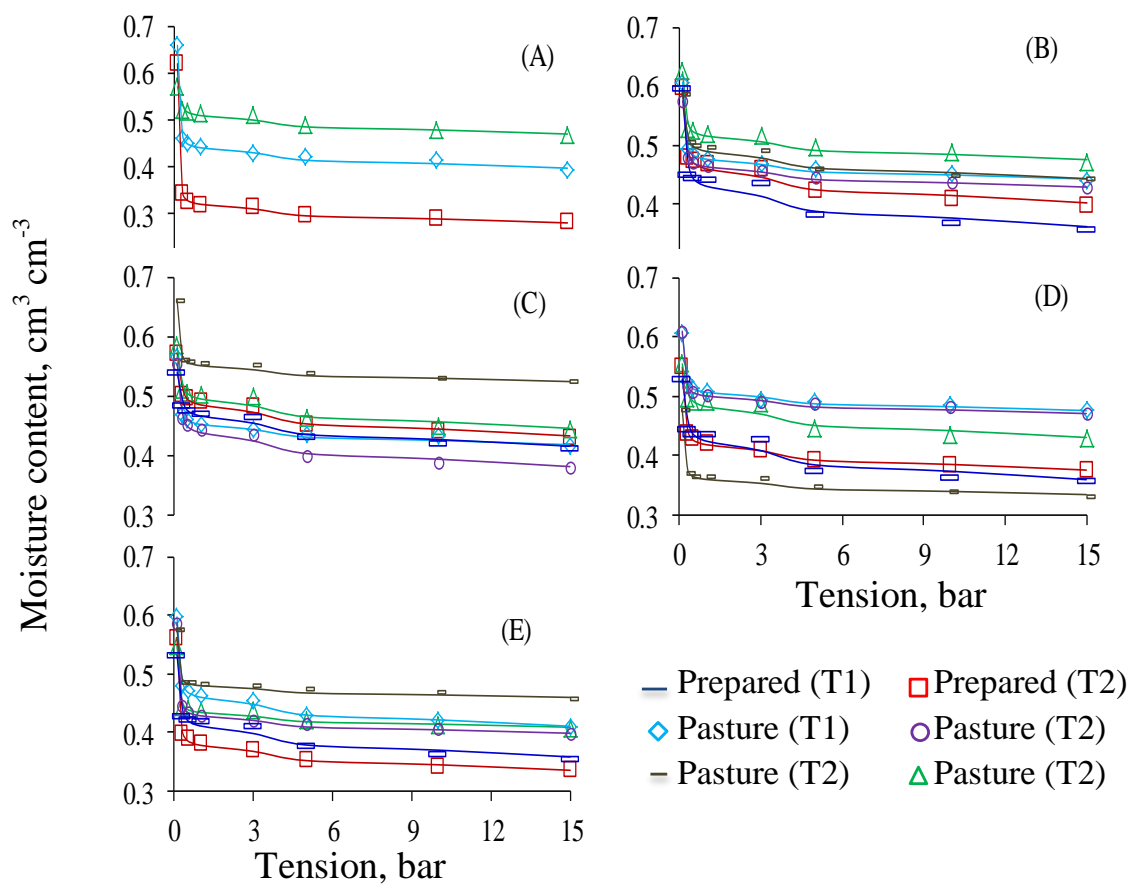

FIGURE 1. Water retention curve for three surfaces, at $10 \mathrm{~cm}$ depth, with 0 passage (A), 1 passage (B), 3 passages (C), 6 passages (D) and 10 passages (E), adjusted with the Van Genuchten model. 


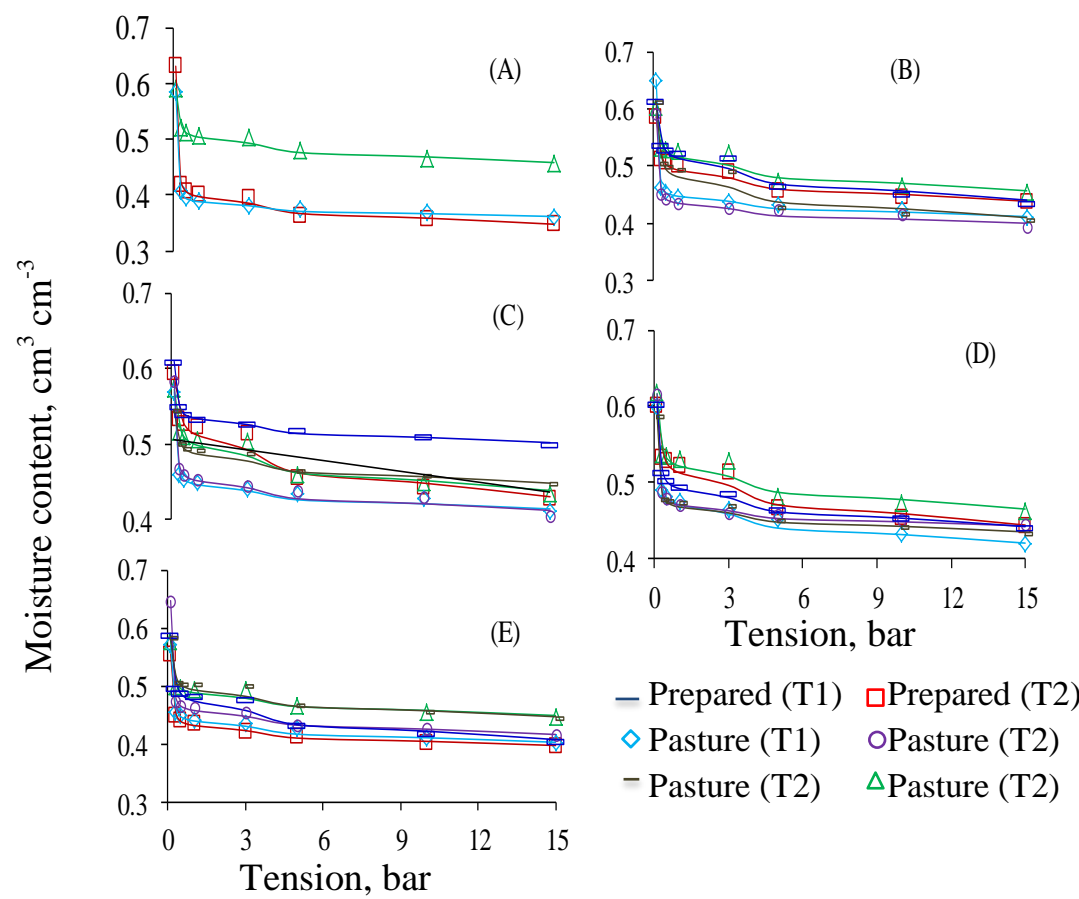

FIGURE 2. Water retention curve for three surfaces, at $30 \mathrm{~cm}$ depth, with 0 passage (A), 1 passage (B), 3 passages (C), 6 passages (D) and 10 passages (E), adjusted with the Van Genuchten model.

Regarding the forms of water in the studied soil, the gravitational water (GW) in the soil shows significant differences between the passages to the studied surfaces (Tables 3 and 4). Values of GW, fluctuate between 5.04 and 29.26\%, category in which PAGLIAI et al. (2003) claim that these should be referred to as moderately porous soils. It is observed low values of GW for P2 and a different behavior regarding to that observed by PAGLIAI et al. (2003), since the tractor traffic did not cause decreases in such property, but the contrary, the increments between passages have emerged in all traffic treatments overcoming the control. For P1 and PR, it was showed decreases between 26.6 and $78.02 \%$ of GW being assessed the greatest reductions in the third, the sixth and the tenth passages of the tractor.

TABLE 3. Gravitational water values (\% volume) founded at $10 \mathrm{~cm}$ depth.

\begin{tabular}{cccccccccc}
\hline \multirow{2}{*}{ Surface } & \multirow{2}{*}{ Control } & \multicolumn{4}{c}{ Trator Passages 1} & \multicolumn{5}{c}{ Trator Passages 2} \\
\cline { 2 - 9 } & & 1 & 3 & 6 & 10 & 1 & 3 & 6 & 10 \\
\hline P1 & $20.75^{\mathrm{bB}}$ & $10.28^{\mathrm{aA}}$ & $10.30^{\mathrm{aA}}$ & $10.22^{\mathrm{aA}}$ & $15.22^{\mathrm{aAB}}$ & $12.24^{\mathrm{abAB}}$ & $10.61^{\mathrm{aA}}$ & $9.19^{\mathrm{aA}}$ & $12.47^{\mathrm{aAB}}$ \\
$\mathrm{PR}$ & $29.26^{\mathrm{CC}}$ & $12.36^{\mathrm{aAB}}$ & $7.58^{\mathrm{aAB}}$ & $11.99^{\mathrm{aAB}}$ & $17.34^{\mathrm{aB}}$ & $14.99^{\mathrm{bAB}}$ & $6.43^{\mathrm{aA}}$ & $9.10^{\mathrm{aAB}}$ & $10.89^{\mathrm{aAB}}$ \\
$\mathrm{P} 2$ & $5.45^{\mathrm{aA}}$ & $10.05^{\mathrm{aA}}$ & $8.00^{\mathrm{aA}}$ & $6.34^{\mathrm{aA}}$ & $10.81^{\mathrm{aA}}$ & $8.62^{\mathrm{aA}}$ & $10.36^{\mathrm{aA}}$ & $11.18^{\mathrm{aA}}$ & $9.13^{\mathrm{A}}$ \\
\hline
\end{tabular}

P1: pasture 1; P2: pasture 2; PR: prepared. Values followed by different lowercase letters in rows or capital letters in columns indicate significant differences according to Tukey test $(\mathrm{P}<0.05)$.

TABLE 4. Gravitational water values (\% volume) founded at $30 \mathrm{~cm}$ depth.

\begin{tabular}{cccccccccc}
\hline \multirow{2}{*}{ Surface } & \multirow{2}{*}{ Control } & \multicolumn{4}{c}{ Trator Passages 1 } & \multicolumn{5}{c}{ Trator Passages 2 } \\
\cline { 2 - 9 } & & 1 & 3 & 6 & 10 & 1 & 3 & 6 & 10 \\
\hline P1 & $19.06^{\mathrm{bA}}$ & $14.80^{\mathrm{aA}}$ & $12.32^{\mathrm{bA}}$ & $13.72^{\mathrm{bA}}$ & $18.05^{\mathrm{bA}}$ & $19.50^{\mathrm{bA}}$ & $11.52^{\mathrm{bA}}$ & $11.75^{\mathrm{aA}}$ & $12.00^{\mathrm{aA}}$ \\
PR & $22.37^{\mathrm{bB}}$ & $8.04^{\mathrm{aA}}$ & $6.86^{\mathrm{abA}}$ & $7.25^{\mathrm{aA}}$ & $11.34^{\mathrm{aA}}$ & $8.50^{\mathrm{aA}}$ & $7.00^{\mathrm{ab} A}$ & $9.95^{\mathrm{aA}}$ & $10.01^{\mathrm{aA}}$ \\
P2 & $7.93^{\mathrm{aA}}$ & $7.52^{\mathrm{aA}}$ & $6.49^{\mathrm{aA}}$ & $8.34^{\mathrm{aA}}$ & $8.09^{\mathrm{aA}}$ & $11.28^{\mathrm{abA}}$ & $5.04^{\mathrm{aA}}$ & $10.99^{\mathrm{aA}}$ & $7.83^{\mathrm{aA}}$ \\
\hline
\end{tabular}

P1: pasture 1; P2: pasture 2; PR: prepared. Values followed by different lowercase letters in rows or capital letters in columns indicate significant differences according to Tukey test $(\mathrm{P}<0.05)$. 
The available water (AW) is at a moisture level between $3.6 \%$ and $10.6 \%$, without noticing significant differences between treatments (Tables 5 and 6). Such values obtained are low, considering the ones reported by DORRONSORO (2007), but similar to those reported by CUNHA et al. (2007), for different crop rotation systems, accepting the statement of LI et al. (2009), who claim that this property is responsible for $89 \%$ of the total water flow, therefore is important to care for this property at the time of traffic machinery application.

TABLE 5. Available water values (\% volume) founded at $10 \mathrm{~cm}$ depth.

\begin{tabular}{cccccccccc}
\hline \multirow{2}{*}{ Surface } & \multirow{2}{*}{ Control } & \multicolumn{4}{c}{ Trator Passages 1} \\
\cline { 3 - 9 } & & 1 & 3 & 6 & 10 & 1 & 3 & 6 & 10 \\
\hline P1 & $6.98^{\mathrm{aA}}$ & $5.22^{\mathrm{aA}}$ & $7.72^{\mathrm{aA}}$ & $5.03^{\mathrm{aA}}$ & $4.71^{\mathrm{aA}}$ & $5.19^{\mathrm{aA}}$ & $5.61^{\mathrm{aA}}$ & $4.87^{\mathrm{aA}}$ & $7.14^{\mathrm{aA}}$ \\
$\mathrm{PR}$ & $5.45^{\mathrm{aA}}$ & $8.14^{\mathrm{aA}}$ & $7.41^{\mathrm{aA}}$ & $5.98^{\mathrm{aA}}$ & $6.16^{\mathrm{aA}}$ & $10.01^{\mathrm{aA}}$ & $6.68^{\mathrm{aA}}$ & $8.73^{\mathrm{bA}}$ & $7.48^{\mathrm{aA}}$ \\
$\mathrm{P} 2$ & $5.70^{\mathrm{aA}}$ & $6.10^{\mathrm{aA}}$ & $6.87^{\mathrm{aA}}$ & $6.97^{\mathrm{aA}}$ & $3.940^{\mathrm{aA}}$ & $6.41^{\mathrm{aA}}$ & $4.21^{\mathrm{aA}}$ & $4.07^{\mathrm{aA}}$ & $3.63^{\mathrm{aA}}$ \\
\hline
\end{tabular}

P1: pasture 1; P2: pasture 2; PR: prepared. Values followed by different lowercase letters in rows or capital letters in columns indicate significant differences according to Tukey test $(\mathrm{P}<0.05)$.

The property constant fluctuations, do not allow to establish a clear vision about the traffic interaction, causing reductions of $32,5 \%$ for $\mathrm{P} 1$, increases of $83 \%$ for $\mathrm{PR}$, without showing reduction in any passage, and finally increases and decreases between $-36.8 \%$ and $22.2 \%$ to $\mathrm{P} 2$.

TABLE 6. Available water values (\% volume) founded at $30 \mathrm{~cm}$ depth.

\begin{tabular}{cccccccccc}
\hline \multirow{2}{*}{ Surface } & \multirow{2}{*}{ Control } & \multicolumn{4}{c}{ Trator passages 1 } & \multicolumn{5}{c}{ Trator Passages 2} \\
\cline { 3 - 9 } & & 1 & 3 & 6 & 10 & 1 & 3 & 6 & 10 \\
\hline P1 & $4.25^{\mathrm{aA}}$ & $5.77^{\mathrm{aA}}$ & $6.11^{\mathrm{aA}}$ & $4.76^{\mathrm{aA}}$ & $6.36^{\mathrm{aA}}$ & $5.53^{\mathrm{aA}}$ & $5.50^{\mathrm{aA}}$ & $8.00^{\mathrm{aA}}$ & $6.02^{\mathrm{aA}}$ \\
$\mathrm{PR}$ & $7.09^{\mathrm{aA}}$ & $7.53^{\mathrm{aA}}$ & $10.70^{\mathrm{aA}}$ & $9.42^{\mathrm{aA}}$ & $5.16^{\mathrm{aA}}$ & $9.93^{\mathrm{aA}}$ & $4.70^{\mathrm{aA}}$ & $7.29^{\mathrm{aA}}$ & $9.70^{\mathrm{aA}}$ \\
$\mathrm{P} 2$ & $6.57^{\mathrm{aA}}$ & $8.17^{\mathrm{aA}}$ & $8.23^{\mathrm{aA}}$ & $7.93^{\mathrm{aA}}$ & $5.81^{\mathrm{aA}}$ & $9.78^{\mathrm{aA}}$ & $5.62^{\mathrm{aA}}$ & $5.09^{\mathrm{aA}}$ & $6.93^{\mathrm{aA}}$ \\
\hline
\end{tabular}

P1: pasture 1; P2: pasture 2; PR: prepared. Values followed by different lowercase letters in rows or capital letters in columns indicate significant differences according to Tukey test $(\mathrm{P}<0.05)$.

The hygroscopic water $(\mathrm{HG})$ in the first $10 \mathrm{~cm}$ depth, can achieve $80.48 \%$ of the total water present in the soil, showing the highest rates in P2 and suffering increases only in the first. For the other surfaces, the tractor passage reported increases, with significant differences in the sixth passage, obtaining there the highest values achieved by this property for P1 and the third passage for PR (Table 7).

TABLE 7. Hygroscopic water values (\% volume) founded at $10 \mathrm{~cm}$ depth.

\begin{tabular}{cccccccccc}
\hline \multirow{2}{*}{ Surface } & \multirow{2}{*}{ Control } & \multicolumn{4}{c}{ Trator Passages 1 } & \multicolumn{5}{c}{ Trator Passages 2} \\
\cline { 3 - 9 } & & 1 & 3 & 6 & 10 & 1 & 3 & 6 & 10 \\
\hline P1 & $38.10^{\mathrm{abA}}$ & $41.99^{\mathrm{abA}}$ & $37.37^{\mathrm{aA}}$ & $45.67^{\mathrm{bA}}$ & $38.84^{\mathrm{aA}}$ & $43.24^{\mathrm{aA}}$ & $40.32^{\mathrm{aA}}$ & $46.57^{\mathrm{aA}}$ & $40.09^{\mathrm{aA}}$ \\
PR & $27.23^{\mathrm{abA}}$ & $39.20^{\mathrm{abB}}$ & $42.25^{\mathrm{aB}}$ & $36.96^{\mathrm{aAB}}$ & $32.70^{\mathrm{aAB}}$ & $34.62^{\mathrm{aAB}}$ & $40.91^{\mathrm{aB}}$ & $35.17^{\mathrm{aAB}}$ & $34.85^{\mathrm{aAB}}$ \\
P2 & $45.96^{\mathrm{bAB}}$ & $46.29^{\mathrm{bAB}}$ & $43.63^{\mathrm{aAB}}$ & $42.25^{\mathrm{abAB}}$ & $40.02^{\mathrm{aAB}}$ & $43.54^{\mathrm{aAB}}$ & $51.48^{\mathrm{aB}}$ & $32.48^{\mathrm{aA}}$ & $44.79^{\mathrm{aAB}}$ \\
\hline
\end{tabular}

P1: pasture 1; P2: pasture 2; PR: prepared. Values followed by different lowercase letters in rows or capital letters in columns indicate significant differences according to Tukey test $(\mathrm{P}<0.05)$.

Regarding the behavior of $\mathrm{HG}$ at $30 \mathrm{~cm}$ depth, this property showed significant differences concerning the control and PR. The behavior of the HG at this depth shows values higher than 10 $\mathrm{cm}$ depth, but its behavior is similar, reaching up to $80.85 \%$ of the water present in the soil in the third passage of tractor 1 (Table 8). 
TABLE 8. Hygroscopic water values (\% volume) founded at $30 \mathrm{~cm}$ depth.

\begin{tabular}{cccccccccc}
\hline \multirow{2}{*}{ Surface } & \multirow{2}{*}{ Control } & \multicolumn{4}{c}{ Trator Passages 1} & \multicolumn{5}{c}{ Trator Passages 2} \\
\cline { 3 - 9 } & & \multicolumn{1}{c}{1} & \multicolumn{1}{c}{3} & 6 & 10 & 1 & 3 & 6 & 10 \\
\hline P1 & $35.3^{\mathrm{aA}}$ & $38.64^{\mathrm{aA}}$ & $39.80^{\mathrm{aA}}$ & $43.12^{\mathrm{aA}}$ & $40.28^{\mathrm{aA}}$ & $40.02^{\mathrm{aA}}$ & $39.83^{\mathrm{aA}}$ & $40.13^{\mathrm{aA}}$ & $38.97^{\mathrm{aA}}$ \\
$\mathrm{PR}$ & $33.71^{\mathrm{aA}}$ & $43.05^{\mathrm{aAB}}$ & $41.91^{\mathrm{aB}}$ & $43.39^{\mathrm{aAB}}$ & $38.97^{\mathrm{aA}}$ & $42.97^{\mathrm{aAB}}$ & $49.24^{\mathrm{bB}}$ & $43.05^{\mathrm{aAB}}$ & $39.10^{\mathrm{aAB}}$ \\
P2 & $44.71^{\mathrm{bA}}$ & $44.67^{\mathrm{aA}}$ & $42.64^{\mathrm{aA}}$ & $45.48^{\mathrm{aA}}$ & $43.86^{\mathrm{aA}}$ & $40.03^{\mathrm{aA}}$ & $43.74^{\mathrm{abA}}$ & $42.52^{\mathrm{aA}}$ & $43.38^{\mathrm{aA}}$ \\
\hline
\end{tabular}

P1: pasture 1; P2: pasture 2; PR: prepared. Values followed by different lowercase letters in rows or capital letters in columns indicate significant differences according to Tukey test $(\mathrm{P}<0.05)$.

Considering the two depths, the values found are above those cited by VEIGA et al. (2008), authors that show fluctuations between $26 \%$ and $33 \%$ of hygroscopic water content. It is worth noting that the percentage that the HG contribution to the total water present in the soil has high values (43.95 to $80.85 \%$ ), considering that this water is not available to the crops.

\section{CONCLUSIONS}

The retention curve presented a typical behavior of compacted soils, with high percentages of unavailable water for the crops, noticing an increase at an overall level in the field capacity values and permanent wilting point as the tractor traffic increases. Furthermore it was observed that the permanent wilting point is transferred to lower pressures as it increases the compaction.

\section{REFERENCES}

ALAOUI, A.; LIPIEC, J.; GERKE, H.H. A review of the changes in the soil pore system due to soil deformation: A hydrodynamic perspective. Soil and Tillage Research, Amsterdam, v.115-116, p.115, 2011.

BOTTA, G.; TOLON BECERRA, A.; BELLORA, F. Effect of the number of tractor passes on soil rut depth and compaction in two tillage regimes. Soil and Tillage Research, Amsterdam, v.103, p.381-386, 2009.

BOTTA, G.F.; VÁZQUEZ, J.M.; TOLON BECERRA, A.; BALBUENA, R.; STADLER, S. Soil compaction distribution under land clearing in calden (Prosopis Caldenia Burkart) forest in Argentinean pampas. Soil and Tillage Research, Amsterdam, v.119, p.70-75, 2012.

CAMACHO-TAMAYO, J.H.; RODRÍGUEZ B., G.A. Evaluación de implementos de labranza a diferentes velocidades de operación y contenidos de agua del suelo. Agricultura Técnica, Chillán, v.67, n.1, p.60-67, 2007.

CUNHA, E.Q.; BALBINO, L.C.; STONE, L.F.; LEANDRO, W.M.; OLIVEIRA, G.C. Influência de rotações de culturas nas propriedades físico-hídricas de um Latossolo Vermelho em plantio direto. Engenharia Agrícola, Jaboticabal, v.27, n.3, p.665-674, 2007.

DIJCK S.; ASCH W. Compaction of loamy soils due to tractor traffic in vineyards and orchards and its effect on infiltration in southern France. Soil and Tillage Research, Amsterdam, v.63, n.3-4, p.141-153, 2002.

DORRONSORO, C. Introducción a la edafología. España: Universidad de Granada, 2007. 100 p.

FLORES, L.; ALCALÁ, J. Manual de procedimientos analíticos. Laboratorio de Física de Suelos. México: Universidad Nacional Autónoma de México, Instituto de Geología, Departamento de Edafología, 2010. 56 p.

FU, X.; SHAO, M.; LU, D.; WANG, H. Soil water characteristic curve measurement without bulk density changes and its implications in the estimation of soil hydraulic properties. Geoderma, Amsterdam, v.167-168, p.1-8, 2011. 
GERSTER. G.R.; BACIGALUPPO, S.; De BATTISTA J.C.; CERANA, J. Distribución de la compactación en el perfil del suelo utilizando diferentes neumáticos. Consecuencias sobre el enraizamiento del cultivo de soja. Argentina.Manfredi: EEA INTA, 2008. p. 68-72. (Serie Para Mejorar la Producción).

GHANBARIAN-ALAVIJEH, B.; LIAGHAT, A.; HUANG, G.; VAN GENUCHTEN, M.T. Estimation of the Van Genuchten soil water retention properties from soil textural data. Pedosphere, Beijing, v.20, n.4, p.456-465, 2010.

IGAC. Estudio general y detallado de suelos de los municipios de Cota, Funza, Mosquera y parte de Madrid. Bogotá: Instituto Geográfico Agustín Codazzi, 1977. 513 p.

INNS, F.M.; KILGOUR, J. Agricultural tires. London: Dunlop, 1978. 69p.

JORAJURIA, D.; DRAGHI, L. Sobrecompactación del suelo agrícola parte I: influencia diferencial del peso y del número de pasadas. Revista Brasileira de Engenharia Agrícola e Ambiental, Campina Grande, v.4, n.3, p.445-452, 2000.

KAMIMURA, K.M.; LEVIEN, L.; TREIN, C.R.; DEBIASI, H.; CONTE, O. Parâmetros solomáquina em função de doses de resíduos vegetais e profundidades de deposição de adubo em semeadura direta. Engenharia Agrícola, Jaboticabal, v.29, n.3, p. 431-439, 2009.

LI, Y.X.; TULLBERG, J.N.; FREEBAIRN, D.M.; LI, H.W. Functional relationships between soil water infiltration and wheeling and rainfall energy. Soil and Tillage Research, Amsterdam, v.104, n.1, p.156-163, 2009.

LIPIEC, J.; WOJCIGA, A.; HORN, R. Hydraulic properties of soil aggregates as influenced by compaction. Soil and Tillage Research, Amsterdam, v.103, n.1, p.170-177, 2009.

MADDEN, N.M.; SOUTHARD, R.J.; MITCHELL, J.P. Soil water and particle size distribution influence laboratory-generated $\mathrm{PM}_{10}$. Atmospheric Environment, Norwich, 44, n.6, p.745-752, 2010.

MEZA, E.; GEISSERT, D. Estructura, agregación y porosidad en suelos forestales y cultivados de origen volcánico del Cofre de Perote, Veracruz, México. Foresta Veracruzana, Xalapa, v.5, n.2, p.57-60, 2003.

PAGLIAI, M.; MARSILI, A.; SERVADIO, P.; VIGNOZZI, N.; PELLEGRINI, S. Changes in some physical properties of a clay soil in Central Italy following the passage of rubber tracked and wheeled tractors of medium power. Soil and Tillage Research, Amsterdam, v.73, n.1, p.119-129, 2003.

PIRES, L.F.; BACCHI, O.O.S.; REICHARDT, K. Soil water retention curve determined by gamma-ray beam attenuation. Soil and Tillage Research, Amsterdam, v.82, n.1, p.89-97, 2005.

SERAFIM, M.E.; VITORINO. A.C.T.; PEIXOTO, P.P.P.; SOUZA, C.M.A; CARVALHO. D.F. Intervalo hídrico ótimo em um latossolo vermelho distroférrico sob diferentes sistemas de produção. Engenharia Agrícola, Jaboticabal, v.28, n.4, p. 654-665, 2008.

SEVERIANO, S.E.; OLIVEIRA, G.C.; DIAS JÚNIOR, M.S.; COSTA, K.A.P.; BENITES, V.M.; FERREIRA FILHO, S.M. Structural changes in latosols of the Cerrado region: II - soil compressive behavior and modeling of additional compaction. Revista Brasileira de Ciência do Solo, Viçosa-MG, v.35, n.3, p.783-791, 2011.

TOLON BECERRA, A.; BOTTA, G.F.; LASTRA BRAVO, X.; TOURN, M.; BELLORA MELCON, F.; VÁZQUEZ, J.; RIVERO, D.; LINARES, P.; NARDON, G. Soil compaction distribution under tractor traffic in almond (Prunus amigdalus L.) orchard in Almería España. Soil and Tillage Research, Amsterdam, v.107, n.1, p.49-56. 2010.

VAN GENUCHTEN, M.T. A closed-form equation for predicting the hydraulic conductivity of unsaturated soils. Soil Science Society of America Journal, Madison, v.44, n.5, p.892-898, 1980. 
VEIGA, M.; REINET, D.J.; REICHERT, J.M.; KAISER, D.R. Short and long-term effects of tillage systems and nutrient sources on soil physical properties of a southern Brazilian Hapludox. Revista Brasileira de Ciência do Solo, Viçosa-MG, v.32, n.4, p.1437-1446, 2008. 